Article

\title{
Calculating Distortions of Short DNA Duplexes with Base Pairing Between an Oxidatively Damaged Guanine and a Guanine
}

\section{Masayo Suzuki, Katsuhito Kino *, Masayuki Morikawa, Takanobu Kobayashi and Hiroshi Miyazawa}

Kagawa School of Pharmaceutical Sciences, Tokushima Bunri University, 1314-1, Shido, Sanuki, Kagawa 769-2193, Japan; E-Mails: s120002@stu.bunri-u.ac.jp (M.S.); s110702@stu.bunri-u.ac.jp (M.M.); kobayashit@kph.bunri-u.ac.jp (T.K.); miyazawah@kph.bunri-u.ac.jp (H.M.)

* Author to whom correspondence should be addressed; E-Mail: kkino@kph.bunri-u.ac.jp; Tel.: +81-87-894-5111; Fax: +81-87-894-0181.

Received: 27 May 2014; in revised form: 17 July 2014 / Accepted: 21 July 2014 /

Published: 28 July 2014

\begin{abstract}
DNA is constantly being oxidized, and oxidized DNA is prone to mutation; moreover, guanine is highly sensitive to several oxidative stressors. Several oxidatively damaged forms of guanine-including 2,2,4-triamino-5(2H)-oxazolone $(\mathrm{Oz})$, iminoallantoin (Ia), and spiroiminodihydantoin (Sp) — can be paired with guanine, and cause G:C-C:G transversions. Previous findings indicate that guanine is incorporated more efficiently opposite $\mathrm{Oz}$ than opposite Ia or $\mathrm{Sp}$, and that these differences in efficiency cannot be explained by differences in the stabilities of G:Oz, G:Ia, and G:Sp base pairs calculated $a b$ initio. Here, to explain previous experimental result, we used a 3-base-pair model DNA duplex to calculate the difference in the stability and the distortion of DNA containing a G:Oz, G:Ia, or G:Sp base pair. We found that the stability of the structure containing $5^{\prime}$ and 3' base pairs adjacent to $\mathrm{G}: \mathrm{Oz}$ was more stable than that containing the respective base pairs adjacent to G:Ia or G:Sp. Moreover, the distortion of the structure in the DNA model duplex that contained a G:Oz was smaller than that containing a G:Ia or G:Sp. Therefore, our discussion can explain the previous results involving translesion synthesis past an oxidatively damaged guanine.
\end{abstract}

Keywords: oxidatively damaged guanine; base pair; distortion of DNA duplex; destabilization energy 


\section{Introduction}

Mutations of genomic information are commonly caused by oxidative stress, and oxidative stressors have been implicated in aging, carcinogenesis, and many other diseases. Guanine is particularly sensitive to several oxidative stressors because it has the lowest oxidation potential among the four bases. Several different oxidative stressors can cause G:C-T:A and G:C-C:G transversions [1]. In fact, $\mathrm{G}: \mathrm{C}-\mathrm{T}: \mathrm{A}$ and $\mathrm{G}: \mathrm{C}-\mathrm{C}: \mathrm{G}$ transversions caused by passive smoking are detected at high frequencies in codon 12 of the $K$-ras gene [2].

Under various oxidative conditions, guanine is oxidized and becomes 8-oxo-7,8-dihydroguanine (8-oxoG) (Scheme 1). Because 8-oxoG can be paired with adenine, but not guanine, 8-oxoG: A base pairs cause only G:C-T:A transversions [3]. Therefore, G:C-C:G transversions are presumably caused by oxidatively damaged guanine. Guanine and 8-oxoG can each be oxidized to 2,2,4-triamino-5(2H)oxazolone (Oz) (Scheme 1) [4]. During DNA replication, DNA polymerase (Pol) $\alpha, \beta, \gamma, \varepsilon, \eta$, I, or IV commonly incorporates guanine opposite $\mathrm{Oz}$ [5-7].

Scheme 1. Oxidation products of guanine and 8-oxoG.<smiles>CCCn1cnc2c(=O)[nH]c(N)nc21</smiles>

guanine<smiles>CC1CCC(NC(N)=NC(=NC(=O)O)C(=O)O)C1</smiles>

$\mathrm{Oz}$<smiles>CCCCCCCCCCCCCCCCCCC</smiles>

8-OxOG

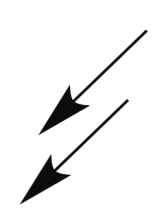

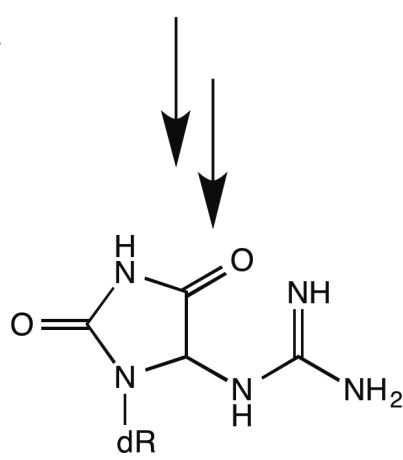

Gh
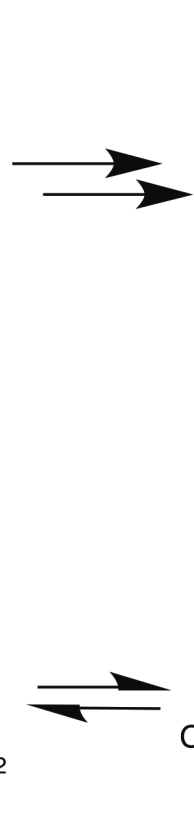

la

Guanidinohydantoin (Gh) and spiroiminodihydantoin ( $\mathrm{Sp}$ ) can be formed via oxidation of 8-oxoG (Scheme 1). Gh is a principal product of 8-oxoG oxidation under acidic conditions, and $\mathrm{Sp}$ is a major product under basic conditions [8-11]. Gh isomerizes to iminoallantoin (Ia) [12], but whether the predominant isomer is Gh or Ia during DNA polymerization is unknown [12]. Based on our previously published calculations of the stability of G:Ia and G:Gh base pairs, Gh is predicted to tautamerize to Ia when guanine is inserted opposite Gh/Ia [13]. Hence, in this study, we consider only Ia. Incorporation of guanine opposite $\mathrm{Oz}$ is more efficient than that opposite $\mathrm{Gh} / \mathrm{Ia}$ or $\mathrm{Sp}$, and translesion synthesis past $\mathrm{Oz}$ is also more efficient than that past $\mathrm{Gh} / \mathrm{Ia}$ or $\mathrm{Sp}[5,7,14]$. However, depending on the number of 
hydrogen bonds, a G:Oz base pair was less stable than either a G:Ia or the G:Sp base pair in our calculated results (Figure 1) [13].

Figure 1. The proposed hydrogen bonding of G:Oz, G:Ia, and G:Sp base pairs.

(a)

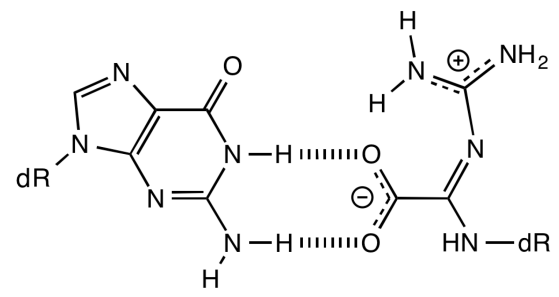

$\mathrm{G}: \mathrm{Oz}$ (b)

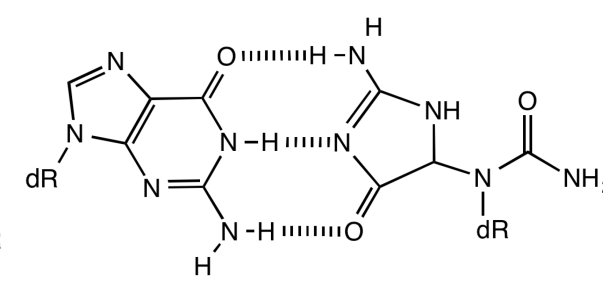

G:la (c)

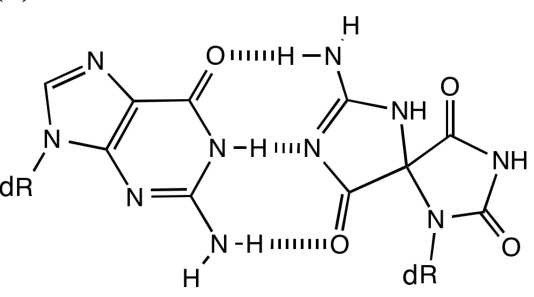

G:Sp

Generally, since replicative DNA polymerases are highly susceptible to geometric distortions in DNA, they have difficulty synthesizing past distorting DNA damage [15]. The previous study showed that the geometry of DNA containing nonplanar DNA damage readily destabilizes and distorts relative to DNA that includes natural Watson-Crick base pairs [16]. Therefore, to resolve the discrepancy between experimental results and calculated results, we focused this study on differences among the distortion of DNA containing these lesions. As depicted in Figure 1, the G:Oz base pair has no $s p^{3}$ carbon and is planar, while G:Ia and G:Sp base pair have a $s p^{3}$ carbon and are nonplanar. Ia and Sp break the planarity of the adjacent base pairs due to a $s p^{3}$ carbon, and as a result, DNA containing Ia or $\mathrm{Sp}$ is easily distorted compared to that containing $\mathrm{Oz}$.

In this study, we tried to explain the experimental results by calculating the differences in the stabilities and distortions of DNA containing a G:Oz, G:Ia, or G:Sp base pair relative to DNA containing a G:C. We use 3-base-pair model DNA duplexes that each contained a central G:Oz, G:Ia, or G:Sp base pair as a way to calculate the differences in stability and distortion.

\section{Results and Discussion}

\subsection{The Minimized Structures of DNA Duplex Containing an X:G Base Pair}

We previously calculated stabilization energies of oxidatively guanine damage $(\mathrm{Oz}, \mathrm{Ia}$ or $\mathrm{Sp})$ paired with guanine [13]. Since Ia and $\mathrm{Sp}$ have a $s p^{3}$ carbon, they have $S$ and $R$ stereoisomers. Our calculated results showed that the stabilization energies of the base pairs, "G:X (where $\mathrm{X}=\mathrm{Oz}, S$-Ia, $R$-Ia, $S$-Sp, or $R$-Sp)", are ordered as follows: G:S-Ia $>\mathrm{G}: R$-Ia $>>\mathrm{G}: R-\mathrm{Sp}>\mathrm{G}: S$-Sp $>>\mathrm{G}: \mathrm{Oz}$ [13]. Here, we investigated differences in stabilities of duplexes containing one $\mathrm{G}: \mathrm{X}$ base pair in the active site of DNA polymerase; each Pol $\beta$-DNA complex containing a G:X base pair was built by modification of the Pol $\beta$ ternary complex (PDB entry 1BPY) [17]. We used the structure of G:X base pair formed the most stable base pair with guanine based on our previous report [13].

Quantum mechanical (QM) calculations are more quantitative than molecular mechanics (MM) calculations. In this study, we used QM calculations only to optimize the most important part of each G:X base pair. However, the Pol $\beta$-DNA complex model had too many atoms to use QM calculations for minimizing the model in an experimentally acceptable amount of time. Therefore, we used MM 
calculations, which are quantitatively inferior to QM calculations, to minimize the Pol $\beta$-DNA model. Only the most important part of each G:X base pair was optimized by QM calculation, and the geometries of Pol $\beta$-DNA complex model were minimized via MM calculations. We focused on the G:X base pair and each of two adjacent base pairs, one $5^{\prime}$ and one $3^{\prime}$ to the central G:X base pair, in each minimized structure (Figures 2 and 3). In Figure 2, the central G: $\mathrm{X}$ base pair was designated " $\mathrm{G}_{2} \mathrm{X}_{2}$ "; the $5^{\prime}$ A:T base pair was designated " $\mathrm{A}_{1} \mathrm{~T}_{1}$ ", and the $3^{\prime} \mathrm{G}: \mathrm{C}$ base pair was designated " $\mathrm{G}_{3} \mathrm{C}_{3}$ ". Minimized geometries of $A_{1} T_{1}, G_{2} X_{2}$ and $G_{3} C_{3}$ base pairs are depicted in Figure 3. We wanted to compare the impact of each $\mathrm{X}_{2}$ on the calculated energies of the duplexes. However, the $\mathrm{X}_{2}$ variants differ from one another in the number of atoms; therefore, the energies of the structures containing different $\mathrm{X}_{2}$ could not be compared directly. Therefore, we focused on the energies of the elements common to each duplex (i.e., $\mathrm{A}_{1} \mathrm{~T}_{1}$ and $\mathrm{G}_{3} \mathrm{C}_{3}$ ) to compare among the energies of the duplexes. By calculating the energies of the common elements and excluding each " $\mathrm{G}_{2} \mathrm{X}_{2}$ " base pair within each structure, we assessed the destabilization caused by the_oxidatively damaged guanine.

\subsection{The Destabilization Energies of the Base Pairs on 5'-and 3'-Side of X}

In this section, in order to evaluate the destabilization of a DNA duplex caused by particular forms of oxidatively damaged guanine, we calculated the destabilization energies of elements common to each structure and excluded each " $\mathrm{G}_{2} \mathrm{X}_{2}$ ” base pair.

Figure 2. An overview of calculating the destabilization energies of DNA duplexes. Each Pol $\beta$-DNA complex containing a $\mathrm{G}: \mathrm{X}$ (where $\mathrm{X}=\mathrm{C}, \mathrm{Oz}, S$-Ia, $R$-Ia, $S$-Sp or $R$-Sp) base pair was minimized. G:X and each base pair adjacent to $G: X$ is delineated in Figure 3. A:T base pair on the 5'-side of $X$ was designated " $A_{1} T_{1}$ ", G: $X$ base pair was designated " $\mathrm{G}_{2} \mathrm{X}_{2}$ ", and $\mathrm{G}: \mathrm{C}$ base pair on the 3 '-side of $\mathrm{X}$ was designated " $\mathrm{G}_{3} \mathrm{C}_{3}$ ". The destabilization energies of " $\mathrm{A}_{1} \mathrm{~T}_{1}$ " $\left(\Delta E_{1}\right)$, " $\mathrm{G}_{3} \mathrm{C}_{3}$ " $\left(\Delta E_{3}\right)$, and " $\mathrm{A}_{1} \mathrm{~T}_{1}+\mathrm{G}_{3} \mathrm{C}_{3}$ " $\left(\Delta E_{1+3}\right)$ were calculated ab initio as the parts common to each model duplex; each $\mathrm{G}_{2} \mathrm{X}_{2}$ base pair was excluded from the calculations.

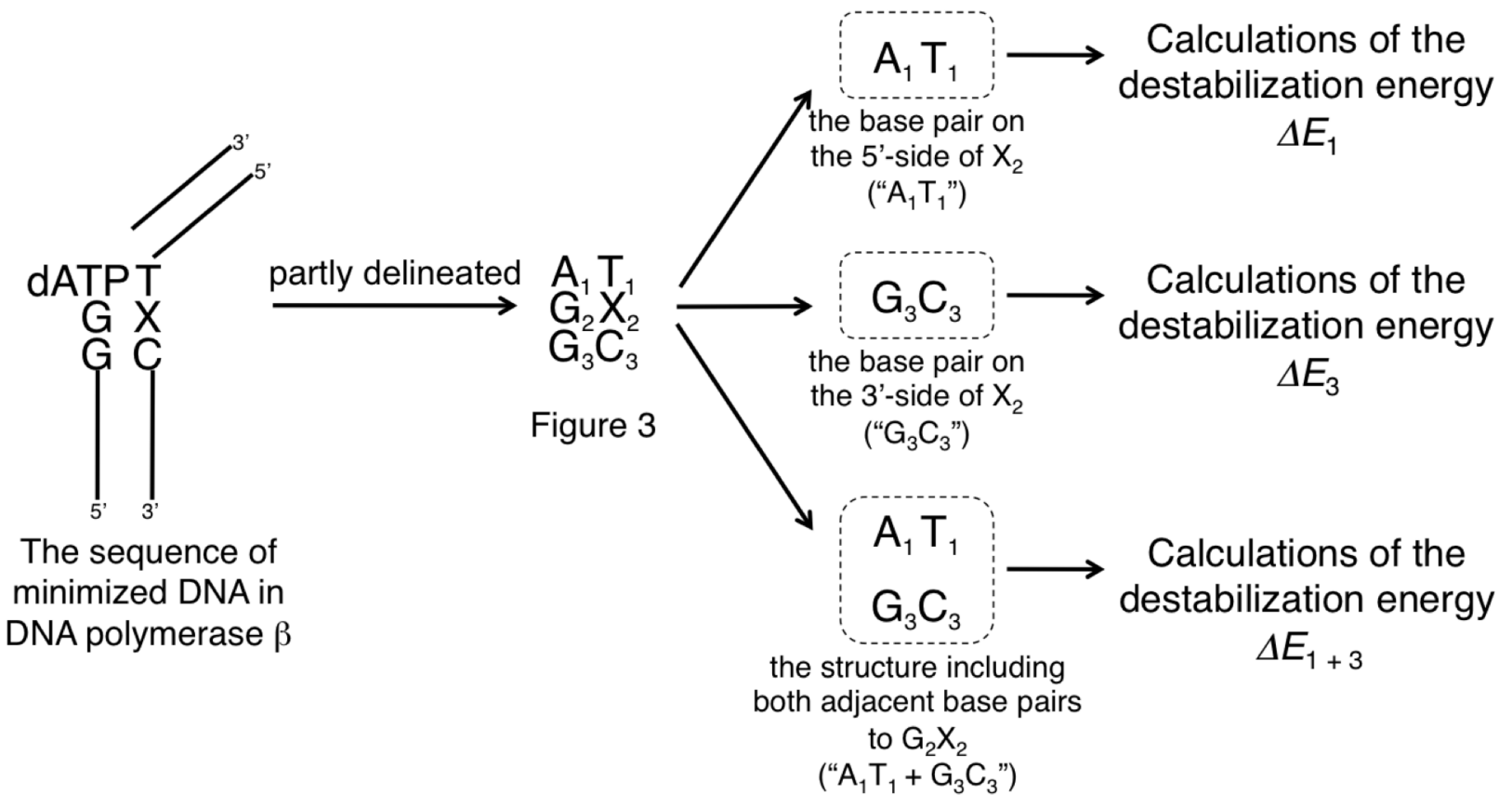


Figure 3. Minimized geometries of " $\mathrm{A}_{1} \mathrm{~T}_{1}, \mathrm{G}_{2} \mathrm{X}_{2}, \mathrm{G}_{3} \mathrm{C}_{3}$ " containing $\mathrm{X}_{2}=(\mathbf{a}) \mathrm{C},(\mathbf{b}) \mathrm{Oz},(\mathbf{c})$ $S$-Ia, (d) $R$-Ia, (e) $S$-Sp, or (f) $R$-Sp as viewed from the minor groove.

(a)

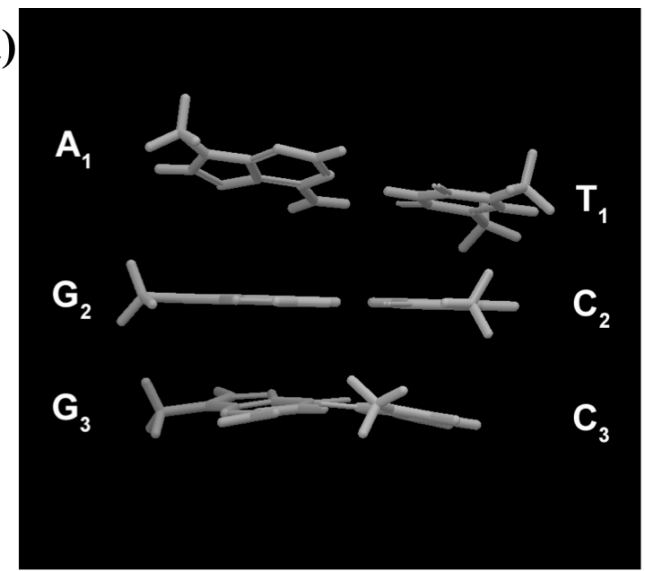

$$
\mathrm{G}_{2} \mathrm{C}_{2}
$$

(c)

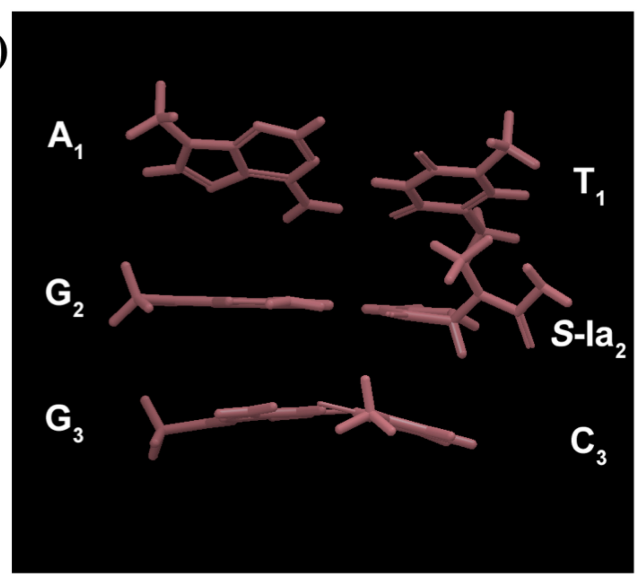

$\mathrm{G}_{2} \mathrm{~S}-\mathrm{Ia}_{2}$

(e)

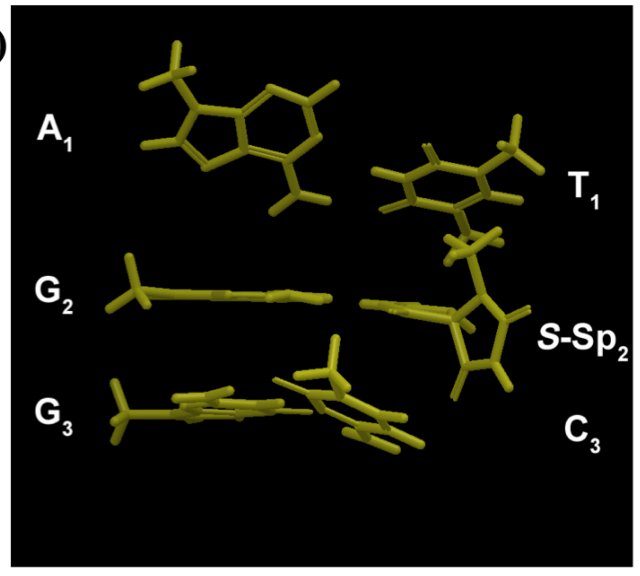

$\mathrm{G}_{2} \mathrm{~S}-\mathrm{Sp}_{2}$ (b)

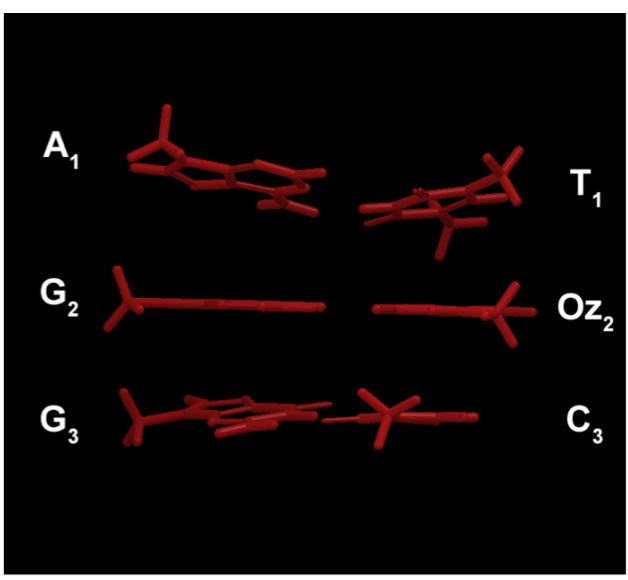

$$
\mathrm{G}_{2} \mathrm{Oz}_{2}
$$

(d)

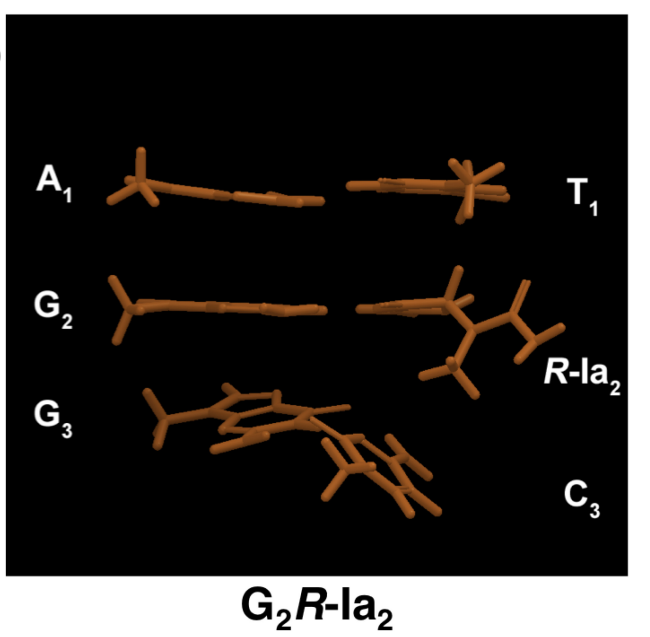

(f)

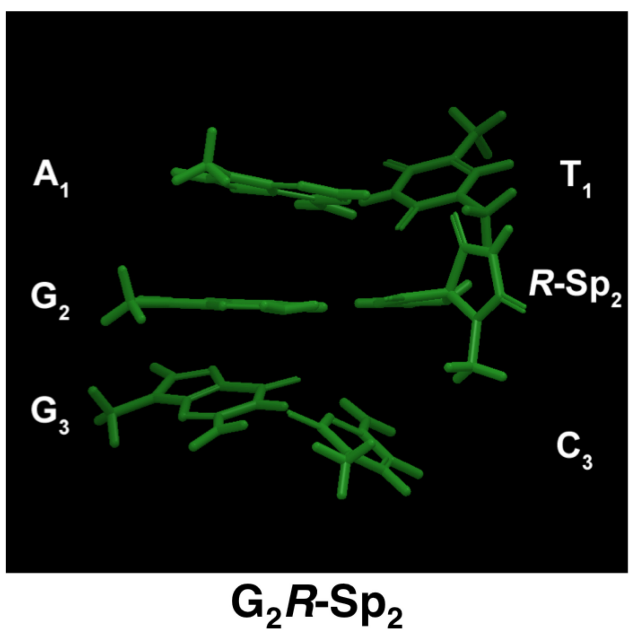

\subsubsection{The Destabilization Energies of the Base Pairs on 5'- Side of X}

We calculated the destabilization energies of each " $\mathrm{A}_{1} \mathrm{~T}_{1}$ " $\left(\Delta E_{1}\right)$ on the 5'-side of each $\mathrm{X}_{2}$. The calculated $\Delta E_{l}$ value associated with duplexes that contained $\mathrm{Oz}, S$-Ia, $R$-Ia, $S$-Sp, or $R$-Sp were defined by Equation (1) (Experimental Section) and were calculated ab initio (Table 1). Values of $\Delta E_{l}$ in vacuo or in water were calculated, and were presented as $\Delta E_{1}{ }^{\mathrm{DFT}}$ and $\Delta E_{1}{ }^{\mathrm{SCRF}}$, respectively. The 
values of $\Delta E_{l}{ }^{\mathrm{DFT}}$ were ordered as follows with respect to each $\mathrm{X}_{2}: R$-Sp $>S$-Sp $>S$-Ia $>\mathrm{Oz}>R$-Ia. The order of $\Delta E_{l}^{\mathrm{SCRF}}$ values in water was the same as the order of $\Delta E_{l}{ }^{\mathrm{DFT}}$ values in vacuo.

Table 1. Destabilization energies (kcal/mol) of " $\mathrm{A}_{1} \mathrm{~T}_{1}$ " $\left(\Delta E_{1}\right)$, " $\mathrm{G}_{3} \mathrm{C}_{3}$ " $\left(\Delta E_{3}\right)$, and " $\mathrm{A}_{1} \mathrm{~T}_{1}+$ $\mathrm{G}_{3} \mathrm{C}_{3}$ " $\left(\Delta E_{1+3}\right)$, each value was calculated with minimized geometries.

\begin{tabular}{|c|c|c|c|c|c|c|}
\hline \multirow[b]{2}{*}{$\mathbf{X}^{a}$} & \multicolumn{2}{|c|}{$\mathbf{A}_{1} \mathbf{T}_{1}$} & \multicolumn{2}{|c|}{$\mathbf{G}_{3} \mathbf{C}_{3}$} & \multicolumn{2}{|c|}{$A_{1} T_{1}+G_{3} C_{3}$} \\
\hline & $\Delta E_{1}^{\mathrm{DFT}}$ & $\Delta E_{1}^{\mathrm{SCRF}}$ & $\Delta E_{3}^{\mathrm{DFT}}$ & $\Delta E_{3}^{\mathrm{SCRF}}$ & $\Delta E_{1+3}{ }^{\mathrm{DFT}}$ & $\Delta E_{1+3}{ }^{\text {SCRF }}$ \\
\hline $\mathrm{Oz}$ & 1.3 & 1.1 & -0.1 & 0.6 & 1.1 & 1.0 \\
\hline$S$-Ia & 1.4 & 1.3 & 2.6 & 1.3 & 4.1 & 4.5 \\
\hline$R$-Ia & 0.5 & 0.6 & 4.0 & 3.9 & 4.8 & 4.6 \\
\hline$S-\mathrm{Sp}$ & 2.1 & 2.1 & 2.7 & 2.8 & 4.8 & 5.3 \\
\hline$R-\mathrm{Sp}$ & 12.6 & 12.4 & 5.3 & 4.5 & 18.3 & 18.3 \\
\hline
\end{tabular}

${ }^{a} \mathrm{X}=$ the damage contained in the minimized structure.

Using kinetic parameters, Kornyushyna et al., demonstrated that incorporation of guanine opposite $\mathrm{Gh} / \mathrm{Ia}$ is more efficient than that opposite $\mathrm{Sp}$ [14]. Our calculated data indicated that " $\mathrm{A}_{1} \mathrm{~T}_{1}$ " on the 5 '-side of Ia was more stable than that of Sp regardless of the stereoisomer, and our data corresponded with these published results. However, our data indicated that " $\mathrm{A}_{1} \mathrm{~T}_{1}$ " on 5 '-side of $\mathrm{Oz}$ was less stable than " $\mathrm{A}_{1} \mathrm{~T}_{1}$ " 5 ' to $R$-Ia, and this finding could not account for the previous experimental finding that translesion synthesis past $\mathrm{Oz}$ is more efficient than that past Ia [5]. Therefore, we calculated the destabilization energies for each $\mathrm{G}_{3} \mathrm{C}_{3}$ base pair on the 3'-side of each $\mathrm{X}_{2}$.

\subsubsection{The Destabilization Energies of the Base Pairs on the 3'-Side of $X$}

The destabilization energies (in vacuo; $\Delta E_{3}{ }^{\mathrm{DFT}}$ and in water; $\Delta E_{3}{ }^{\mathrm{SCRF}}$ ) of " $\mathrm{G}_{3} \mathrm{C}_{3}$ " were defined by Equation (2) (Experimental Section), and were calculated individually (Table 1). The values of $\Delta E_{3}^{\text {DFT }}$ and $\Delta E_{3}{ }^{\mathrm{SCRF}}$ were ordered as follows with regard to each $\mathrm{X}_{2}: R$-Sp $>R$-Ia $>S$-Sp $>S$-Ia $>$ Oz. Surprisingly, the calculated values for $\Delta E_{3}{ }^{\mathrm{DFT}}$ and $\Delta E_{3}{ }^{\mathrm{SCRF}}$ of $\mathrm{Oz}$ were the lowest among the values for any $\mathrm{X}_{2}$, and " $\mathrm{G}_{3} \mathrm{C}_{3}$ " on 3 '-side of $\mathrm{Oz}$ was the most stable.

The stabilities of the " $\mathrm{G}_{3} \mathrm{C}_{3}$ " base pairs on the 3'-side of $\mathrm{X}_{2}$ were consistent with previous experimental results indicating that translesion synthesis past $\mathrm{Oz}$ is more efficient than that past Ia or $\mathrm{Sp}[5,14]$. The " $\mathrm{G}_{3} \mathrm{C}_{3}$ " base pairs on 3'-side of $S$-Sp was more stable than that of $R$-Ia; consequently, it was not possible to fully explain the previous experimental results based on the stabilities of $\mathrm{G}_{3} \mathrm{C}_{3}$ base pairs on the 3'-side of $\mathrm{X}_{2}$. Consequently, we then considered the stability of the larger structure by examining the energies of the structure containing both base pairs ( $5^{\prime}$ and $3^{\prime}$ ) adjacent to each $\mathrm{X}_{2}$.

2.2.3. The Destabilization Energy of Each Model Duplex was Calculated by Including both Adjacent Base Pairs and Excluding the Central " $\mathrm{G}_{2} \mathrm{X}_{2}$ " Base Pair

The destabilization energy of $\mathrm{A}_{1} \mathrm{~T}_{1}+\mathrm{G}_{3} \mathrm{C}_{3}$ (in vacuo; $\Delta E_{1+3}{ }^{\mathrm{DFT}}$ and in water; $\Delta E_{1+3}{ }^{\mathrm{SCRF}}$ ) was calculated for each structure, including both adjacent base pairs and excluding the central " $\mathrm{G}_{2} \mathrm{X}_{2}$ " base pair. These values were calculated with Equation (3) (Experimental Section) (Table 1). The lowest $\Delta E_{1+3}{ }^{\mathrm{DFT}}$ and $\Delta E_{1+3}{ }^{\mathrm{SCRF}}$ values among all values calculated for any $\mathrm{X}_{2}$ were the values for Oz. Values of $\Delta E_{1+3}{ }^{\text {DFT }}$ and $\Delta E_{1+3}{ }^{\text {SCRF }}$ for Ia were lower than those for Sp, and $S$ configurations were more stable 
than $R$ configurations for both Ia and Sp. Taken together, values of $\Delta E_{1+3}{ }^{\text {DFT }}$ for the guanine oxidation products were ordered as follows for the $\mathrm{X}_{2}$ variants: $R$-Sp $>S$-Sp $\sim R$-Ia $>S$-Ia $>\mathrm{Oz}$, and values of $\Delta E_{1+3}{ }^{\text {SCRF }}$ were ordered as follows: $R$-Sp $>S$-Sp $>R$-Ia $>S$-Ia $>$ Oz.

" $\mathrm{A}_{1} \mathrm{~T}_{1}+\mathrm{G}_{3} \mathrm{C}_{3}$ " with $\mathrm{Oz}$ was more stable than that with any other $\mathrm{X}_{2}$; this finding indicated that a DNA structure containing $\mathrm{G}_{2} \mathrm{Oz}_{2}$ was more similar to DNA containing $\mathrm{G}_{2} \mathrm{C}_{2}$ than was that with any other $\mathrm{G}_{2}$ : $\mathrm{X}_{2}$ base pair. As mentioned in the introduction; the geometry of DNA that includes nonplanar DNA damage is easy to destabilize and distort relative to that containing natural Watson-Crick base pairs [16]; and DNA polymerases have difficulty synthesizing through distorted DNA [15]. Therefore; our calculated values could account for the previous experimental findings that translesion synthesis across $\mathrm{Oz}$ is more efficient than that across Ia or $\mathrm{Sp}[5,14]$.

Notably, the calculated $\Delta E_{1+3}{ }^{\text {DFT }}$ values for $R$-Ia and $S$-Sp were not consistent with previous results [14]. Actual experiments involving DNA polymerization have been performed in aqueous solution [5,14]; therefore, the stability of DNA duplex during DNA polymerization is attributed to the energy in water $\left(\Delta E_{1+3}{ }^{\mathrm{SCRF}}\right) \cdot \Delta E_{1+3}{ }^{\mathrm{SCRF}}$ for $R$-Ia was lower than $\Delta E_{1+3}$ SCRF for $S$-Sp, which can account for the previous result [14]. Furthermore, the calculated stabilities of " $\mathrm{A}_{1} \mathrm{~T}_{1}+\mathrm{G}_{3} \mathrm{C}_{3}$ " with $S$-Sp or $R$-Sp could explain why bypass of $S$-Sp is more efficient than bypass of $R$-Sp in vivo [18].

In conclusion, although calculating either energies of " $\mathrm{A}_{1} \mathrm{~T}_{1}$ " on the 5 '-side of $\mathrm{X}_{2}$ or energies of " $\mathrm{G}_{3} \mathrm{C}_{3}$ " on the 3 '-side of $\mathrm{X}_{2}$ was not sufficient, calculating energies of the structure while including both base pairs, " $A_{1} T_{1}+G_{3} C_{3}$ ", adjacent to " $\mathrm{G}_{2} \mathrm{X}_{2}$ " was sufficient to evaluate the stability of the DNA duplex containing an G:Oz, G:Ia, or G:Sp base pair. In the next section, we used parameterized distortion of DNA to examine the effects of the non-planarity of $\mathrm{Oz}, S$-Ia, $R$-Ia $S$-Sp, or $R$-Sp on $\mathrm{A}_{1} \mathrm{~T}_{1}$ base pairs and $\mathrm{G}_{3} \mathrm{C}_{3}$ base pairs in DNA duplexes that each contain one central $\mathrm{G}$ :X base pair.

\subsection{The Degree of Distortion from DNA Duplex Containing a G:C Base Pair}

Based on the images in Figure 3, we received the visual impression that there were differences in the degree of distortion among the DNA duplexes that contained $\mathrm{C}, \mathrm{Oz}, S$-Ia, $R$-Ia $S$-Sp, or $R$-Sp. Because abstract visual impressions were insufficient for detailed comparisons among the structures, it was necessary to parameterize actual values for those visual impressions. In this section, we examined differences in the degree of distortion caused by each G:X base pair to parameterize the distortion of each DNA duplex.

\subsubsection{The Degree of Distortion at the 5'-Side of X}

In order to determine the degree of distortion at the 5'-side of each $\mathrm{G}_{2} \mathrm{X}_{2}$ base pair, we calculated the dihedral angles $(\theta)$ between $\mathrm{G}_{2}$ and $\mathrm{A}_{1}\left(\theta\left(\mathrm{G}_{2}-\mathrm{A}_{1}\right)\right)$ or $\mathrm{G}_{2}$ and $\mathrm{T}_{1}\left(\theta\left(\mathrm{G}_{2}-\mathrm{T}_{1}\right)\right)$ or $\mathrm{A}_{1}$ and $\mathrm{T}_{1}\left(\theta\left(\mathrm{A}_{1}-\mathrm{T}_{1}\right)\right)$ (red arrows in Figure 4). Values for $\theta\left(\mathrm{G}_{2}-\mathrm{A}_{1}\right), \theta\left(\mathrm{G}_{2}-\mathrm{T}_{1}\right)$, and $\theta\left(\mathrm{A}_{1}-\mathrm{T}_{1}\right)$ were each calculated individually via Equations (5)-(7), respectively (Experimental Section). The degree of distortion $\left(\delta_{1}\right)$ on the 5'-side of $\mathrm{G}_{2} \mathrm{X}_{2}$ was defined as the sum of $\theta\left(\mathrm{G}_{2}-\mathrm{A}_{1}\right), \theta\left(\mathrm{G}_{2}-\mathrm{T}_{1}\right)$, and $\theta\left(\mathrm{A}_{1}-\mathrm{T}_{1}\right)$ (Equation (11) in Experimental Section). In Table 2, the values of $\delta_{l}$ were ordered as follows with regard to $\mathrm{X}_{2}$ variants: $S$-Sp $>R$-Sp $>S$-Ia $>\mathrm{Oz}>\mathrm{C}>R$-Ia. 
Figure 4. Calculated dihedral angle $\theta\left(\mathrm{G}_{2}-\mathrm{A}_{1}\right), \theta\left(\mathrm{G}_{2}-\mathrm{T}_{1}\right)$ and $\theta\left(\mathrm{A}_{1}-\mathrm{T}_{1}\right)$ showed red arrows, and the calculated dihedral angle $\theta\left(\mathrm{G}_{2}-\mathrm{G}_{3}\right), \theta\left(\mathrm{G}_{2}-\mathrm{C}_{3}\right)$ and $\theta\left(\mathrm{G}_{3}-\mathrm{C}_{3}\right)$ showed blue arrows.

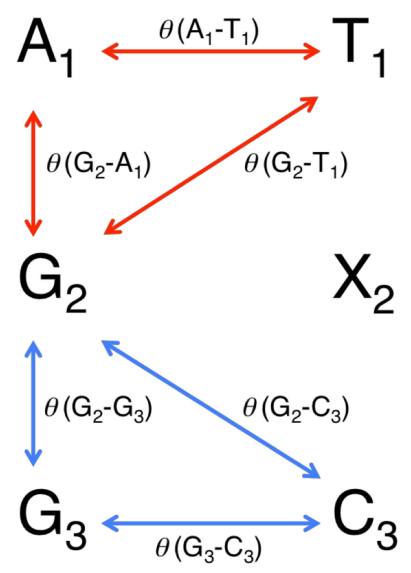

Table 2. Dihedral angles $\theta\left(\mathrm{G}_{2}-\mathrm{A}_{1}\right), \theta\left(\mathrm{G}_{2}-\mathrm{T}_{1}\right)$, and $\theta\left(\mathrm{A}_{1}-\mathrm{T}_{1}\right)$ (red arrows in Figure 4$)$, and the degree of distortion $\delta_{l}$.

\begin{tabular}{ccccc}
\hline $\mathbf{X}^{\boldsymbol{a}}$ & $\boldsymbol{\theta}\left(\mathbf{G}_{2}-\mathbf{A}_{1}\right)$ & $\boldsymbol{\theta}\left(\mathbf{G}_{2}-\mathbf{T}_{1}\right)$ & $\boldsymbol{\theta}\left(\mathbf{A}_{1}-\mathbf{T}_{1}\right)$ & $\boldsymbol{\delta}_{\boldsymbol{I}}$ \\
\hline $\mathrm{C}$ & $25.2^{\circ}$ & $12.5^{\circ}$ & $13.3^{\circ}$ & $51.0^{\circ}$ \\
$\mathrm{Oz}$ & $19.4^{\circ}$ & $18.2^{\circ}$ & $18.0^{\circ}$ & $55.6^{\circ}$ \\
$S$-Ia & $38.3^{\circ}$ & $28.2^{\circ}$ & $11.3^{\circ}$ & $77.8^{\circ}$ \\
$R$-Ia & $3.3^{\circ}$ & $4.0^{\circ}$ & $4.0^{\circ}$ & $11.3^{\circ}$ \\
$S$-Sp & $56.1^{\circ}$ & $29.9^{\circ}$ & $26.4^{\circ}$ & $112.4^{\circ}$ \\
$R$-Sp & $10.9^{\circ}$ & $32.4^{\circ}$ & $43.2^{\circ}$ & $86.5^{\circ}$ \\
\hline \multicolumn{5}{c}{$\mathrm{X}=$ the damage contained in the minimized structure. }
\end{tabular}

Based on the values of $\delta_{l}$, the distortion of " $\mathrm{A}_{1} \mathrm{~T}_{1}$ " base pair adjacent to $R$-Ia is the smallest, and this structure was similar to the structure of the " $\mathrm{A}_{1} \mathrm{~T}_{1}$ " derived from DNA duplex containing a $\mathrm{G}_{2} \mathrm{C}_{2}$ (Table 1, Figure 3a,d). Consequently, the calculated $\Delta E_{1}$ for $R$-Ia was the lowest for all $\mathrm{X}_{2}$ variant. Furthermore, the order of calculated $\Delta E_{1}$ values with respect to $\mathrm{X}_{2}$ variants $-S$-Ia $>\mathrm{Oz}>$ $R$-Ia-coincided with the order of $\delta_{l}$. Thus, since a large $\delta_{l}$ indicates a prominent distortion of $\mathrm{A}_{1} \mathrm{~T}_{1}$, we believe that the destabilization of $\mathrm{A}_{1} \mathrm{~T}_{1}$ base pair could result from by the distortions caused by the $\mathrm{X}_{2}$ variants. However, $\Delta E_{1}$ values with $R$-Sp or $S$-Sp could not be explained by $\delta_{l}$ caused by $R$-Sp or $S$-Sp. Furthermore, $\delta_{l}$ values for $S$ configurations were larger than those for $R$ configurations both for Ia and for Sp. The C1' methyl of $S$-Ia or $S$-Sp was oriented in the direction of the " $\mathrm{A}_{1} \mathrm{~T}_{1}$ " base pair (Figure 3c,e); therefore, the effects of the $S$ configurations on 5 '-side of $\mathrm{X}_{2}$ were larger than those of the $R$ configurations. In summary, $\delta_{l}$ values could not explain previous experimental results, nor could they completely account for $\Delta E_{l}$ values.

\subsubsection{The Degree of Distortion at the 3'-Side of $X$}

As with 5'-side of $\mathrm{X}_{2}$ (in Section 2.3.1), we calculated the dihedral angle $\theta$ between $\mathrm{G}_{2}$ and $\mathrm{G}_{3}$ $\left(\theta\left(\mathrm{G}_{2}-\mathrm{G}_{3}\right)\right)$, or $\mathrm{G}_{2}$ and $\mathrm{C}_{3}\left(\theta\left(\mathrm{G}_{2}-\mathrm{C}_{3}\right)\right)$, or $\mathrm{G}_{3}$ and $\mathrm{C}_{3}\left(\theta\left(\mathrm{G}_{3}-\mathrm{C}_{3}\right)\right)$ (blue arrows in Figure 4$)$. Values for $\theta$ $\left(\mathrm{G}_{2}-\mathrm{G}_{3}\right), \theta\left(\mathrm{G}_{2}-\mathrm{C}_{3}\right)$, and $\theta\left(\mathrm{G}_{3}-\mathrm{C}_{3}\right)$ were each calculated individually via Equations (8)-(10), respectively (Experimental Section). The degree of distortion $\left(\delta_{3}\right)$ at the 3 '-side of $\mathrm{X}_{2}$ was defined as 
the sum of $\theta\left(\mathrm{G}_{2}-\mathrm{G}_{3}\right), \theta\left(\mathrm{G}_{2}-\mathrm{C}_{3}\right)$, and $\theta\left(\mathrm{G}_{3}-\mathrm{C}_{3}\right)$ (Equation (12) in Experimental Section). All numeric values are listed in Table 3. For the $\mathrm{X}_{2}$ residues, the order of values for $\delta_{3}$ was as follows: $R$-Ia $>R$-Sp $>S$-Sp $>S$-Ia $>$ C $>$ Oz.

Table 3. Dihedral angles $\theta\left(\mathrm{G}_{2}-\mathrm{G}_{3}\right), \theta\left(\mathrm{G}_{2}-\mathrm{C}_{3}\right)$, and $\theta\left(\mathrm{G}_{3}-\mathrm{C}_{3}\right)$ (blue arrows in Figure 4), and the degree of distortion $\delta_{3}$.

\begin{tabular}{ccccc}
\hline $\mathbf{X}^{\boldsymbol{a}}$ & $\boldsymbol{\theta}\left(\mathbf{G}_{\mathbf{2}}-\mathbf{G}_{3}\right)$ & $\boldsymbol{\theta}\left(\mathbf{G}_{2}-\mathbf{C}_{\mathbf{3}}\right)$ & $\boldsymbol{\theta}\left(\mathbf{G}_{3}-\mathbf{C}_{3}\right)$ & $\boldsymbol{\delta}_{3}$ \\
\hline $\mathrm{C}$ & $9.5^{\circ}$ & $8.0^{\circ}$ & $17.2^{\circ}$ & $34.6^{\circ}$ \\
$\mathrm{Oz}$ & $11.1^{\circ}$ & $3.1^{\circ}$ & $11.9^{\circ}$ & $26.1^{\circ}$ \\
$S$-Ia & $5.4^{\circ}$ & $13.9^{\circ}$ & $19.2^{\circ}$ & $38.5^{\circ}$ \\
$R$-Ia & $17.9^{\circ}$ & $42.6^{\circ}$ & $49.2^{\circ}$ & $109.7^{\circ}$ \\
$S$-Sp & $5.5^{\circ}$ & $25.7^{\circ}$ & $23.2^{\circ}$ & $54.4^{\circ}$ \\
$R$-Sp & $22.9^{\circ}$ & $36.2^{\circ}$ & $43.3^{\circ}$ & $102.5^{\circ}$ \\
\hline \multicolumn{5}{c}{$\mathrm{X}=$ the damage contained in the minimized structure. }
\end{tabular}

When comparing among the $\mathrm{X}_{2}$ variants, the " $\mathrm{G}_{3} \mathrm{C}_{3}$ " adjacent to $\mathrm{Oz}$ was the least distorted based on the values of $\delta_{3}$, and the most similar in structure to the " $\mathrm{G}_{3} \mathrm{C}_{3}$ in a DNA duplex containing a $\mathrm{G}_{2} \mathrm{C}_{2}$ (Figure 3a,b). Additionally, the calculated $\Delta E_{3}$ with $\mathrm{Oz}$ was lowest, and the order of $\mathrm{X}_{2}$ variants with regard to calculated $\Delta E_{3}$ values $-S$-Sp $>S$-Ia $>\mathrm{Oz}$ (Table 1) —was consistent with the order of $\delta_{3}$ values. As was the case with $\delta_{l}$ (showed in section 2.3.1), the destabilization of the $\mathrm{G}_{3} \mathrm{C}_{3}$ base pair could be accounted for by the distortion caused by the $\mathrm{G}_{2} \mathrm{X}_{2}$ base pair. In contrast to $\delta_{1}$ values, $\delta_{3}$ values associated with $R$ configurations were larger than those associated with $S$ configurations for both Ia and $\mathrm{Sp}$; moreover, the $\mathrm{C} 1$ ' methyl of $R$-Ia or $R$-Sp was oriented in the direction of the " $\mathrm{G}_{3} \mathrm{C}_{3}$ " base pair (Figure 3d,f). Consequently, the $\mathrm{C}_{3}$ base of $R$-Ia or $R$-Sp was particularly distorted by the $\mathrm{C}^{\prime}$ ' methyl of $R$-Ia or $R$-Sp, respectively. Taken together, $\delta_{3}$ values could not account for $\Delta E_{3}$ values or previous experimental results, as was the case for $\delta_{l}$ values.

\subsubsection{The Total Degree of Distortion at the 5'-Side and 3'-Side of X}

The total degree of distortion (" $\delta_{1}+\delta_{3}$ ") at the 5'- and 3'-side of $\mathrm{X}_{2}$ was defined as the sum of $\delta_{1}$ and $\delta_{3}$ (Table 4 ). The " $\delta_{1}+\delta_{3}$ " values were ordered as follows with regard to $\mathrm{X}_{2}$ variants: $R$-Sp $>S$-Sp $>R$-Ia $>S$-Ia $>\mathrm{C}>\mathrm{Oz}$. This order was consistent with the order of the calculated energies $\left(\Delta E_{1+3}\right)$. Although the value of " $\delta_{1}+\delta_{3}$ " for $\mathrm{Oz}$ was smaller than that for $\mathrm{C}$, the structure of " $\mathrm{A}_{1} \mathrm{~T}_{1}+\mathrm{G}_{3} \mathrm{C}_{3}$ " adjacent to " $\mathrm{G}_{2} \mathrm{Oz}_{2}$ " was less stable than that to " $\mathrm{G}_{2} \mathrm{C}_{2}$ " according to $\Delta E_{1+3}$ : The stabilities of the structure of " $\mathrm{A}_{1} \mathrm{~T}_{1}+\mathrm{G}_{3} \mathrm{C}_{3}$ " were only partially explained by the degree of distortion.

Table 4. Total degree of distortion (" $\delta_{1}+\delta_{3}$ ").

\begin{tabular}{cc}
\hline $\mathbf{X}^{a}$ & $\delta_{1}+\delta_{3}$ \\
\hline $\mathrm{C}$ & $85.6^{\circ}$ \\
$\mathrm{Oz}$ & $81.7^{\circ}$ \\
$S$-Ia & $116.3^{\circ}$ \\
$R$-Ia & $121.1^{\circ}$ \\
$S$-Sp & $166.8^{\circ}$ \\
$R$-Sp & $189.0^{\circ}$ \\
\hline
\end{tabular}

${ }^{a} \mathrm{X}=$ the damage contained in the minimized structure. 
2.3.4. The Difference Between the Degree of Distortion for Oxidatively Damaged Guanine and that for C

We tried to eliminate the discordance between the distortion and the stability in " $\mathrm{G}_{2} \mathrm{Oz}_{2}$ " and " $\mathrm{G}_{2} \mathrm{C}_{2}$ ". Instead of a simple comparison among the values of the degree of distortion for any $\mathrm{X}_{2}$, we calculated the difference between the value of $\delta_{1}+\delta_{3}$ for $\mathrm{C}$ and that for Oz, $S$-Ia, $R$-Ia, $S$-Sp or $R$-Sp as well as the destabilization energy. We found that the values of $\delta_{l}+\delta_{3}$ for $S$-Ia or $R$-Ia differed from that for $\mathrm{C}$ by $30.7^{\circ}$ or $35.4^{\circ}$, respectively; in contrast, there was only slight difference of $4.0^{\circ}$ between that for $\mathrm{Oz}$ and that for $\mathrm{C}$. The distortion of the structure of " $\mathrm{A}_{1} \mathrm{~T}_{1}+\mathrm{G}_{3} \mathrm{C}_{3}$ " adjacent to " $\mathrm{G}_{2} \mathrm{Oz}_{2}$ " was smaller than that adjacent to " $\mathrm{G}_{2} S$ - $\mathrm{Ia}_{2}$ " or " $\mathrm{G}_{2} R-\mathrm{Ia}_{2}$ ", which seemed consistent with visual impressions. Additionally, the values of $\delta_{1}+\delta_{3}$ for $S$-Sp or $R$-Sp differed from that of C by $81.1^{\circ}$ or $103.3^{\circ}$, respectively. These values indicated that the structures of " $\mathrm{A}_{1} \mathrm{~T}_{1}+\mathrm{G}_{3} \mathrm{C}_{3}$ " adjacent to " $\mathrm{G}_{2} S-\mathrm{Sp}_{2}$ " or " $\mathrm{G}_{2} R-\mathrm{Sp}_{2}$ " were the most distorted from that adjacent to " $\mathrm{G}_{2} \mathrm{C}_{2}$ "; these findings seemed consistent with the visual impression of the images in Figure 3. These discussions accounted for the differences among the calculated energies $\left(\Delta E_{1+3}\right)$ of the structure of " $\mathrm{A}_{1} \mathrm{~T}_{1}+\mathrm{G}_{3} \mathrm{C}_{3}$ " adjacent to " $\mathrm{G}_{2} \mathrm{X}_{2}$ ".

In addition to the values of $\delta_{1}+\delta_{3}$, the values of $\delta_{l}$ or $\delta_{3}$ for Oz, $S$-Ia, $R$-Ia, $S$-Sp, or $R$-Sp were compared with that for $\mathrm{C}$. The distortions of each $\mathrm{X}_{2}$-containing structure compared to the value of $\delta_{l}$ for $\mathrm{C}$ was ordered as follows with regard to $\mathrm{X}_{2}$ variants: $S$-Sp $>R$-Ia $>R$-Sp $>S$-Ia $>\mathrm{Oz}$ : That of $\delta_{3}$ was ordered as follows: $R$-Ia $>R$-Sp $>S$-Sp $>\mathrm{Oz}>S$-Ia. Therefore, the distortion for each $\mathrm{X}_{2}$ compared the value of $\delta_{1}$ or $\delta_{3}$ for $\mathrm{C}$ was not consistent with the visual impression, unlike the values of $\delta_{l}+\delta_{3}$, which were consistent with the visual impressions.

In summary, the previous experimental results were only partially explained by either $\delta_{1}$ or $\delta_{3}$ (Sections 2.3.1 and 2.3.2); however, " $\delta_{1}+\delta_{3}$ " compensated for the weaknesses of each single measure by summing $\delta_{1}$ and $\delta_{3}$. Consequently, " $\delta_{1}+\delta_{3}$ " was able to account for the previous experimental results and $\Delta E_{1+3}$. According to our data, the structure of " $\mathrm{A}_{1} \mathrm{~T}_{1}+\mathrm{G}_{3} \mathrm{C}_{3}$ " adjacent to " $\mathrm{G}_{2} \mathrm{X}_{2}$ " was distorted by the effects of the non-planarity of each lesion; in other words, the instability of a DNA duplex containing oxidatively damaged guanine was determined by the non-planarity of each oxidatively damaged guanine. Thus, it seemed reasonable that the projected distortion of a DNA duplex containing a $\mathrm{G}: \mathrm{Oz}$ base pair would be the smallest.

\section{Experimental}

\subsection{Molecular Modeling}

In this study, we constructed models of Pol $\beta$-DNA complexes containing a $\mathrm{G}: \mathrm{X}$ (where $\mathrm{X}=\mathrm{C}, \mathrm{Oz}$, $S$-Ia, $R$-Ia, $S$-Sp, or $R$-Sp) base pair using the structure (PDBID:1BPY) [17]. The details of method used to construct these models are presented below. In each model, the incoming nucleotide (dCTP) was replaced with dATP, and the template G for the incoming nucleotide was replaced with T. Each complex containing Pol $\beta$ and a G:X base pair was built by replacing the G:C base pair at the 3' terminus of the template-primer with $\mathrm{G}: \mathrm{X}$ base pair optimized previously [13]. The amino acid residues and other DNA base sequences were unchanged. The geometry of each atom was minimized at the OPLS2005/water level using Macromodel 9.0 (Schrödinger LLC, New York) with the fixed G:X base pair. 


\section{2. ab Initio Calculations}

For each minimized structure, all atoms were removed from the Pol $\beta$-DNA model except for (1) constituents of the bases of each G:X base pair, (2) constituents of the bases of each base pair adjacent to the G:X base pair, (3) the 2-deoxyribose $\mathrm{C} 1$ ' carbon, and (4) the $\mathrm{C} 1{ }^{\prime} \mathrm{H}$. Two $\mathrm{H}$ atoms were then attached to the $\mathrm{C} 1$ ' methine to complete the $\mathrm{N}$-methylated nucleobases (Figure 2) [5]. As mentioned in Section 2.1, the designation " $\mathrm{A}_{1} \mathrm{~T}_{1}$ ", " $\mathrm{G}_{2} \mathrm{X}_{2}$ ", and " $\mathrm{G}_{3} \mathrm{C}_{3}$ " were used for the consecutive base pairs (Figures 2 and 3 ).

Gaussian 03 (Gaussian Inc., Wallingford, CT, USA) [19] was used to calculate the destabilization energy of " $\mathrm{A}_{1} \mathrm{~T}_{1}$ " $\left(\Delta E_{l}\right)$ of each G:X complex in vacuo at the B3LYP/6-31G** level. Moreover, to estimate the energy of each " $\mathrm{A}_{1} \mathrm{~T}_{1}$ " base pair in water, the Onsanger reaction field model and a dielectric constant of 78.39 were used to calculate the SCRF value of each of these base pairs. The destabilization energies of each " $\mathrm{G}_{3} \mathrm{C}_{3}$ " $\left(\Delta E_{3}\right)$ were calculated in vacuo and in water, just as $\Delta E_{1}$ values were calculated. The destabilization energies of " $\mathrm{A}_{1} \mathrm{~T}_{1}+\mathrm{G}_{3} \mathrm{C}_{3}$ " $\left(\Delta E_{1+3}\right)$ were calculated in vacuo and in water. The calculated destabilization energies $\left(\Delta E_{1}, \Delta E_{3}\right.$, and $\left.\Delta E_{1+3}\right)$ are defined in Equations (1)-(3).

$$
\begin{aligned}
& \Delta E_{1}=E\left(\text { “ } \mathrm{A}_{1} \mathrm{~T}_{1} \text { ” of } \mathrm{G}: \mathrm{X} \text { complex }(\mathrm{X}=\mathrm{C})\right) \\
& -E \text { (“' } \mathrm{A}_{1} \mathrm{~T}_{1} \text { ” of G:X complex (X= Oz, } S \text {-Ia, } R \text {-Ia, } S \text {-Sp or } R \text {-Sp)) } \\
& \Delta E_{3}=E\left(\text { " } \mathrm{G}_{3} \mathrm{C}_{3} \text { " of } \mathrm{G}: \mathrm{X} \text { complex }(\mathrm{X}=\mathrm{C})\right) \\
& -E\left(“ \mathrm{G}_{3} \mathrm{C}_{3} \text { ” of G:X complex (X }=\mathrm{Oz}, S \text {-Ia, } R \text {-Ia, } S \text {-Sp or } R\right. \text {-Sp)) } \\
& \Delta E_{1+3}=E\left(\text { “ } \mathrm{A}_{1} \mathrm{~T}_{1}+\mathrm{G}_{3} \mathrm{C}_{3} \text { ” of } \mathrm{G}: \mathrm{X} \text { complex }(\mathrm{X}=\mathrm{C})\right) \\
& -E\left({ }^{\prime \prime} \mathrm{A}_{1} \mathrm{~T}_{1}+\mathrm{G}_{3} \mathrm{C}_{3} \text { ” of G:X complex (X }=\mathrm{Oz}, S \text {-Ia, } R \text {-Ia, } S \text {-Sp or } R\right. \text {-Sp)) }
\end{aligned}
$$

\subsection{Calculating the Degree of Distortion}

We calculated values for the vectors $C 5 N 1$ and $C 5 N 3$ using the $\mathrm{C} 5\left(\mathrm{x}_{\mathrm{C} 5}, \mathrm{y}_{\mathrm{C} 5}, \mathrm{z}_{\mathrm{C} 5}\right), \mathrm{N} 1\left(\mathrm{x}_{\mathrm{N} 1}, \mathrm{y}_{\mathrm{N} 1}\right.$, $\left.\mathrm{z}_{\mathrm{N} 1}\right), \mathrm{N} 3\left(\mathrm{x}_{\mathrm{N} 3}, \mathrm{y}_{\mathrm{N} 3}, \mathrm{z}_{\mathrm{N} 3}\right)$ atoms for each of five bases $\mathrm{A}_{1}, \mathrm{~T}_{1}, \mathrm{G}_{2}, \mathrm{G}_{3}$, and $\mathrm{C}_{3}$ (Figure 5a). The normal vector $\boldsymbol{P}_{n}$ was calculated from vectors $\boldsymbol{C 5 N 1}$ and $\boldsymbol{C 5 N 3}$ (Equation (4)) (Figure 5b), and $n$ represented $\mathrm{A}_{1}, \mathrm{~T}_{1}, \mathrm{G}_{2}, \mathrm{G}_{3}$, or $\mathrm{C}_{3}$ :

$$
\begin{gathered}
\boldsymbol{P}_{n}\left(\mathrm{x}_{\mathrm{n}}, \mathrm{y}_{\mathrm{n}}, \mathrm{z}_{\mathrm{n}}\right)=\boldsymbol{C} \mathbf{5 N 1} \times \boldsymbol{C 5 N 3} \\
=\left(\mathrm{x}_{\mathrm{N} 1}-\mathrm{x}_{\mathrm{C} 5}, \mathrm{y}_{\mathrm{N} 1}-\mathrm{y}_{\mathrm{C} 5}, \mathrm{z}_{\mathrm{N} 1}-\mathrm{z}_{\mathrm{C} 5}\right) \times\left(\mathrm{x}_{\mathrm{N} 3}-\mathrm{x}_{\mathrm{C} 5}, \mathrm{y}_{\mathrm{N} 3}-\mathrm{y}_{\mathrm{C} 5}, \mathrm{z}_{\mathrm{N} 3}-\mathrm{z}_{\mathrm{C} 5}\right) \\
=\left(\left(\mathrm{y}_{\mathrm{N} 1}-\mathrm{y}_{\mathrm{C} 5}\right) \cdot\left(\mathrm{z}_{\mathrm{N} 3}-\mathrm{z}_{\mathrm{C} 5}\right)-\left(\mathrm{z}_{\mathrm{N} 1}-\mathrm{z}_{\mathrm{C} 5}\right) \cdot\left(\mathrm{y}_{\mathrm{N} 3}-\mathrm{y}_{\mathrm{C} 5}\right),\left(\mathrm{z}_{\mathrm{N} 1}-\mathrm{z}_{\mathrm{C} 5}\right) \cdot\left(\mathrm{x}_{\mathrm{N} 3}-\mathrm{x}_{\mathrm{C} 5}\right)-\left(\mathrm{x}_{\mathrm{N} 1}-\mathrm{x}_{\mathrm{C} 5}\right) \cdot\left(\mathrm{z}_{\mathrm{N} 3}-\mathrm{z}_{\mathrm{C} 5}\right),\right. \\
\left.\left(\mathrm{x}_{\mathrm{N} 1}-\mathrm{x}_{\mathrm{C} 5}\right) \cdot\left(\mathrm{y}_{\mathrm{N} 3}-\mathrm{y}_{\mathrm{C} 5}\right)-\left(\mathrm{y}_{\mathrm{N} 1}-\mathrm{y}_{\mathrm{C} 5}\right) \cdot\left(\mathrm{x}_{\mathrm{N} 3}-\mathrm{x}_{\mathrm{C} 5}\right)\right)
\end{gathered}
$$


Figure 5. (a) Vector $\boldsymbol{C} 5 \mathrm{~N} 1$ and vector $\boldsymbol{C} 5 \mathrm{N3}$ in A, T, G, or C. (b) Normal vector $\boldsymbol{P}_{n}$ was calculated from $C 5 N 1$ and vector $C 5 N 3$ (Equation (4)).

(a)

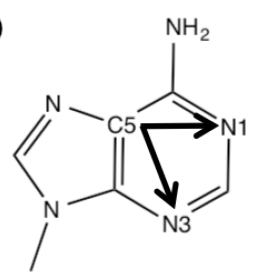

A

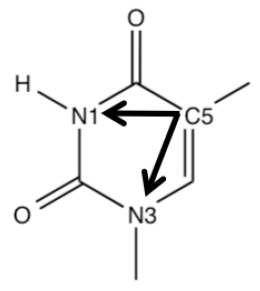

$\mathbf{T}$

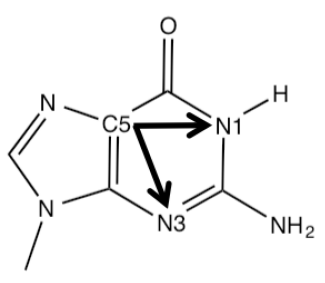

G

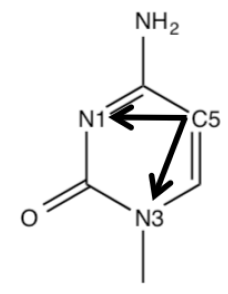

C

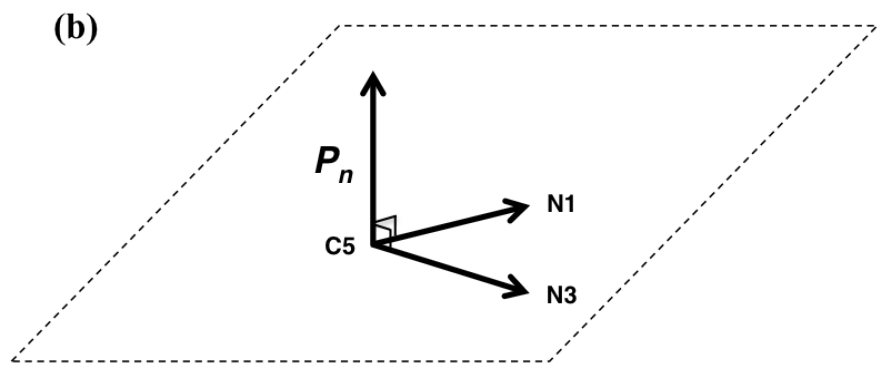

Next, we calculated the dihedral angles between $G_{2}$ and $A_{1}\left(\theta\left(G_{2}-A_{1}\right)\right), G_{2}$ and $T_{1}\left(\theta\left(G_{2}-T_{1}\right)\right), A_{1}$ and $T_{1}\left(\theta\left(A_{1}-T_{1}\right)\right), G_{2}$ and $G_{3}\left(\theta\left(G_{2}-G_{3}\right)\right), G_{2}$ and $C_{3}\left(\theta\left(G_{2}-C_{3}\right)\right)$, or $G_{3}$ and $C_{3}\left(\theta\left(G_{3}-C_{3}\right)\right)$ (Figure 4) using the two respective normal vectors (Equations (5)-(10)):

$$
\begin{gathered}
\theta\left(\mathrm{G}_{2}-\mathrm{A}_{1}\right)=\arccos \left(\boldsymbol{P}_{G 2} \bullet \boldsymbol{P}_{A 1} /\left|\boldsymbol{P}_{G 2}\right|\left|\boldsymbol{P}_{A 1}\right|\right) \\
\theta\left(\mathrm{G}_{2}-\mathrm{T}_{1}\right)=\arccos \left(\boldsymbol{P}_{G 2} \bullet \boldsymbol{P}_{T 1} /\left|\boldsymbol{P}_{G 2}\right|\left|\boldsymbol{P}_{T 1}\right|\right) \\
\theta\left(\mathrm{A}_{1}-\mathrm{T}_{1}\right)=\arccos \left(\boldsymbol{P}_{A 1} \bullet \boldsymbol{P}_{T 1}|| \boldsymbol{P}_{A 1}|| \boldsymbol{P}_{T 1} \mid\right) \\
\theta\left(\mathrm{G}_{2}-\mathrm{G}_{3}\right)=\arccos \left(\boldsymbol{P}_{G 2} \bullet \boldsymbol{P}_{G 3} /\left|\boldsymbol{P}_{G 2}\right|\left|\boldsymbol{P}_{G 3}\right|\right) \\
\theta\left(\mathrm{G}_{2}-\mathrm{C}_{3}\right)=\arccos \left(\boldsymbol{P}_{G 2} \bullet \boldsymbol{P}_{C 3}|| \boldsymbol{P}_{G 2}|| \boldsymbol{P}_{C 3} \mid\right) \\
\theta\left(\mathrm{G}_{3}-\mathrm{C}_{3}\right)=\arccos \left(\boldsymbol{P}_{G 3} \bullet \boldsymbol{P}_{C 3} /\left|\boldsymbol{P}_{G 3}\right|\left|\boldsymbol{P}_{C 3}\right|\right)
\end{gathered}
$$

As an index of the distortion of the DNA duplex, we defined the degree of distortion $\left(\delta_{1}\right.$ and $\left.\delta_{3}\right)$ (Equations (11) and (12)).

$$
\begin{aligned}
& \delta_{1}=\theta\left(\mathrm{G}_{2}-\mathrm{A}_{1}\right)+\theta\left(\mathrm{G}_{2}-\mathrm{T}_{1}\right)+\theta\left(\mathrm{A}_{1}-\mathrm{T}_{1}\right) \\
& \delta_{3}=\theta\left(\mathrm{G}_{2}-\mathrm{G}_{3}\right)+\theta\left(\mathrm{G}_{2}-\mathrm{C}_{3}\right)+\theta\left(\mathrm{G}_{3}-\mathrm{C}_{3}\right)
\end{aligned}
$$

\section{Conclusions}

Previous experimental results show that incorporation of guanine is more efficient when the template base is $\mathrm{Oz}$ than when it is Ia or Sp; however, the difference between $\mathrm{Oz}$ and Ia or $\mathrm{Sp}$ is not explained by the stabilities of G:Oz, G:Ia, and G:Sp as calculated $a b$ initio. Thus, we focused on 
differences among G:Oz, G:Ia, and G:Sp with regard to planarity of base pair, and tried to explain the previous experimental results based on differences in distortion of DNA containing these DNA lesion.

Using models of 3-base-pair DNA duplexes that each contained a variable central " $\mathrm{G}_{2} \mathrm{X}_{2}$ " base pair, we calculated the destabilization energies of the parts common to each model relative to energy of the structure derived from DNA containing a central $\mathrm{G}_{2} \mathrm{C}_{2}$ base pair. For the five $\mathrm{X}_{2}$ variants, we found that the stabilities of the " $\mathrm{A}_{1} \mathrm{~T}_{1}$ " base pairs on the 5'-side of $\mathrm{X}_{2}$ were ordered as follows: $R$-Ia $>\mathrm{Oz}>$ $S$-Ia $>S$-Sp $>R$-Sp, and that the stabilities of the " $\mathrm{G}_{3} \mathrm{C}_{3}$ " base pairs on the 3'-side of $\mathrm{X}_{2}$ were ordered as follows: $\mathrm{Oz}>S$-Ia $>S$-Sp $>R$-Ia $>R$-Sp. These data could not explain the previous experimental results. We also calculated the stability of the structure including both adjacent base pairs and excluding the central " $\mathrm{G}_{2} \mathrm{X}_{2}$ " (" $\mathrm{A}_{1} \mathrm{~T}_{1}+\mathrm{G}_{3} \mathrm{C}_{3}$ "); we found that, for the five $\mathrm{X}_{2}$ variants, the stability of " $\mathrm{A}_{1} \mathrm{~T}_{1}+\mathrm{G}_{3} \mathrm{C}_{3}$ " was ordered as follows: $\mathrm{Oz}>S$-Ia $>R$-Ia $>S$-Sp $>R$-Sp. The previous experimental results could be explained by considering the stability of the structure when accounting for both the $5^{\prime}$ and 3 ' sides of $\mathrm{X}_{2}$.

Additionally, we parameterized the distortion of DNA duplex in order to examine the effects of $\mathrm{Oz}$, $S$-Ia, $R$-Ia $S$-Sp, or $R$-Sp. The degree of distortion at the 5 '-side of $\mathrm{X}_{2}\left(\delta_{l}\right)$ or at the 3 '-side of $\mathrm{X}_{2}\left(\delta_{3}\right)$ could not explain the stability of " $\mathrm{A}_{1} \mathrm{~T}_{1}$ " or " $\mathrm{G}_{3} \mathrm{C}_{3}$ ", respectively, or the previous experimental results. However, compared with the structure of DNA containing a central $\mathrm{G}_{2} \mathrm{C}_{2}$ base pair, the total degree of distortion (" $\delta_{1}+\delta_{3}$ ") at the $5^{\prime}$ and $3^{\prime}$ sides of $\mathrm{X}_{2}$ were ordered as follows for the five $\mathrm{X}_{2}$ variants: $R$-Sp $>>S$-Sp $>R$-Ia $>S$-Ia $>>$ Oz. Values " $\delta_{1}+\delta_{3}$ " coincided with the stabilities of " $\mathrm{A}_{1} \mathrm{~T}_{1}+\mathrm{G}_{3} \mathrm{C}_{3}$ ", and either calculation could account for the previous experimental results. Taken together, our discussions indicated that DNA containing a nonplanar lesion was susceptible to distortion and to destabilization, and consequently the bypass efficiency of DNA polymerase at the more nonplanar lesion was reduced relative to that at the more planar lesion. We showed that calculating energies of the structure accounting for both base pairs adjacent to G:Oz, G:Ia, or G:Sp was sufficient to evaluate the stability of the DNA duplex containing any of these base pairs. The distortion of the structure of DNA a duplex containing a central G:Oz was smaller than that of DNA containing a G:Ia or G:Sp; therefore, a G:Oz base pair was more easily bypassed by DNA polymerase than was a G:Ia or G:Sp base pair.

In this study, to minimize by MM calculation, we used the models contained not only the residues of protein and base pairs but also the sugar and phosphate components. There are not, however, the sugar and phosphate components in the DNA models used QM calculation of the stability, because models containing these components cannot calculate in a realistically acceptable amount of time due to many atoms. Therefore, to explain the more accurate effect of distortion caused these DNA damages, it will need to be considered how distortion within the bases can lead to changes in sugar conformation in the future.

\section{Acknowledgments}

This work was supported by K. Kino's research grants from Japan Society for the Promotion of Science (JSPS), from Tokushima Bunri University, Japan Prize Foundation, from Radiation Effects Association. M. Suzuki and M. Morikawa were supported by a Research Fellowship from JSPS for Young Scientists. 


\section{Author Contributions}

K. Kino and M. Suzuki conceived of this study and designed the calculations. M. Suzuki performed the calculations. M. Suzuki and K. Kino analyzed the data. All the authors discussed the results, in particular, K. Kino, M. Morikawa and T. Kobayashi contributed with valuable discussions about calculations and scientific input. M. Suzuki, K. Kino and H. Miyazawa wrote the paper. All the authors have read and approved the final manuscript.

\section{Conflicts of Interest}

The authors declare no conflict of interest.

\section{References}

1. Kino, K.; Sugiyama, H. UVR-induced G-C to C-G transversions from oxidative DNA damage. Mutat. Res. 2005, 571, 33-42.

2. Maehira, F.; Miyagi, I.; Asato, T.; Eguchi, Y.; Takei, H.; Nakatsuki, K.; Fukuoka, M.; Zaha, F. Alterations of protein kinase C, 8-hydroxydeoxyguanosine, and $\mathrm{K}$-ras oncogene in rat lungs exposed to passive smoking. Clin. Chim. Acta 1999, 289, 133-144.

3. Shibutani, S.; Takeshita, M.; Grollman, A.P. Insertion of specific bases during DNA synthesis past the oxidation-damaged base 8-oxodG. Nature 1991, 349, 431-434.

4. Cadet, J.; Berger, M.; Buchko, G.W.; Joshi, P.C.; Raoul, S.; Ravanat, J.-L. 2,2-Diamino-4-[(3,5di-O-acetyl-2-deoxy- $\beta$-D-erythro-pentofuranosyl)amino]-5-(2H)-oxazolone: A novel and predominant radical oxidation product of 3',5'-di-O-acetyl-2'-deoxyguanosine. J. Am. Chem. Soc. 1994, 116, 7403-7404.

5. Kino, K.; Sugasawa, K.; Mizuno, T.; Bando, T.; Sugiyama, H.; Akita, M.; Miyazawa, H.; Hanaoka, F. Eukaryotic DNA polymerases $\alpha, \beta$ and $\varepsilon$ incorporate guanine opposite 2,2,4-triamino-5(2H)-oxazolone. ChemBioChem 2009, 10, 2613-2616.

6. Duarte, V.; Gasparutto, D.; Jaquinod, M.; Cadet, J. In vitro DNA synthesis opposite oxazolone and repair of this DNA damage using modified oligonucleotides. Nucleic Acids Res. 2000, 28, $1555-1563$.

7. Kino, K.; Ito, N.; Sugasawa, K.; Sugiyama, H.; Hanaoka, F. Translesion synthesis by human DNA polymerase $\eta$ across oxidative products of guanine. Nucleic Acids Symp. Ser. 2004, 48, 171-172.

8. Luo, W.; Muller, J.G.; Rachlin, E.M.; Burrows, C.J. Characterization of spiroiminodihydantoin as a product of one-electron oxidation of 8-oxo-7,8-dihydroguanosine. Org. Lett. 2000, 2, 613-616.

9. Kino, K.; Morikawa, M.; Kobayashi, T.; Kobayashi, T.; Komori, R.; Sei, Y.; Miyazawa, H. The oxidation of 8-oxo-7,8-dihydroguanine by iodine. Bioorg. Med. Chem. Lett. 2010, 20, 3818-3820.

10. Munk, B.H.; Burrows, C.J.; Schlegel, H.B. An exploration of mechanisms for the transformation of 8-oxoguanine to guanidinohydantoin and spiroiminodihydantoin by density functional theory. J. Am. Chem. Soc. 2008, 130, 5245-5256.

11. Ye, Y.; Munk, B.H.; Muller, J.G.; Cogbill, A.; Burrows, C.J.; Schlegel, H.B. Mechanistic aspects of the formation of guanidinohydantoin from spiroiminodihydantoin under acidic conditions. Chem. Res. Toxicol. 2009, 22, 526-535. 
12. Luo, W.; Muller, J.G.; Rachlin, E.M.; Burrows, C.J. Characterization of hydantoin products from one-electron oxidation of 8-oxo-7,8-dihydroguanosine in a nucleoside model. Chem. Res. Toxicol. 2001, 14, 927-938.

13. Suzuki, M.; Kino, K.; Morikawa, M.; Kobayashi, T.; Komori, R.; Miyazawa, H. Calculation of the stabilization energies of oxidatively damaged guanine base pairs with guanine. Molecules 2012, 17, 6705-6715.

14. Kornyushyna, O.; Berges, A.M.; Muller, J.G.; Burrows, C.J. In vitro nucleotide misinsertion opposite the oxidized guanosine lesions spiroiminodihydantoin and guanidinohydantoin and DNA synthesis past the lesions using escherichia coli DNA Polymerase I (Klenow Fragment). Biochemistry 2002, 41, 15304-15314.

15. Prakash, S.; Prakash, L. Translesion DNA synthesis in eukaryotes: A one- or two-polymerase affair. Genes Dev. 2002, 16, 1872-1883.

16. Wu, M.; Yan, S.; Patel, D.J.; Geacintov, N.E.; Broyde, S. Relating repair susceptibility of carcinogen-damaged DNA with structural distortion and thermodynamic stability. Nucleic Acids Res. 2002, 30, 3422-3432.

17. Sawaya, M.R.; Prasad, R.; Wilson, S.H.; Kraut, J.; Pelletier, H. Crystal structures of human DNA polymerase $\beta$ complexed with gapped and nicked DNA: Evidence for an induced fit mechanism. Biochemistry 1997, 36, 11205-11215.

18. Neeley, W.L.; Delaney, S.; Alekseyev, Y.O.; Jarosz, D.F.; Delaney, J.C.; Walker, G.C.; Essigmann, J.M. DNA polymerase $\mathrm{V}$ allows bypass of toxic guanine oxidation products in vivo. J. Biol. Chem. 2007, 282, 12741-12748.

19. Frisch, M.J.; Trucks, G.W.; Schlegel, H.B.; Scuseria, G.E.; Robb, M.A.; Cheeseman, J.R.; Montgomery, J.A.; Vreven, T., Jr.; Kudin, K.N.; Burant, J.C.; et al. Gaussian 03, Revision C.02; Gaussian, Inc.: Wallingford, CT, USA, 2004.

Sample Availability: Not available.

(C) 2014 by the authors; licensee MDPI, Basel, Switzerland. This article is an open access article distributed under the terms and conditions of the Creative Commons Attribution license (http://creativecommons.org/licenses/by/3.0/). 